\title{
Authenticity and affect in historical reenactments of the Russian Revolution on social media
}

\section{Yagodin, Dmitry}

Routledge

2019

Yagodin , D 2019 , Authenticity and affect in historical reenactments of the Russian Revolution on social media . in M Wijermars \& K Lehtisaari (eds), Freedom of Expression in Russia's New Mediasphere . , 6 , BASEES/Routledge Series on Russian and East European Studies , Routledge , Abingdon , pp. 115-133 . https://doi.org/10.4324/9780429437205-7

http://hdl.handle.net/10138/330150

https://doi.org/10.4324/9780429437205-7

acceptedVersion

Downloaded from Helda, University of Helsinki institutional repository.

This is an electronic reprint of the original article.

This reprint may differ from the original in pagination and typographic detail.

Please cite the original version. 


\section{Authenticity and affect in historical reenactments of the Russian Revolution on social media}

Dmitry Yagodin

\section{Introduction}

What has Anna Pavlova got to do with the Russian Revolution of 1917? The famous ballet dancer left Russia a few years before the revolution and never returned. However, a short film showing Pavlova dancing at the National Theatre in Havana, Cuba, in February of 1917 has been among the most popular Facebook post in a history reenactment project called Project '1917 Free History' (Project 1917 2017). The project was headed by a Russian journalist named Mikhail Zygar and a group of volunteers. During the year 2017, it reconstructed the revolution in the form of a social networking website. Moderators created accounts for real historical characters and interpreted 1917 through social media messages and interactions. Archival documents, quotes and photographs provided the content. Both the project's authors and the audience considered Pavlova's performance relevant to the context of the revolution. Another reenactment project called \#1917Live, launched by the Russian international broadcaster RT, stood out in a different manner. \#1917Live interpreted the Russian Revolution via a communication network on Twitter. Arguably, the project's most notable outcome was a scandal regarding the suspended Twitter account of the historical UK Embassy in the Russian Empire. British authorities complained, and Twitter agreed - \#1917Live used official UK symbols without consent.

These two examples preface my argument in this chapter - past and present controversies reinforce each other in historical media projects, while customized experiences of history on 
social media may lead to a lower level of authenticity and higher emotional response. Decisive in this process are the socio-political contexts wherein certain episodes of history become public. Thus, public discussion of history via state-controlled and independent media is the subject through which this chapter contributes to the book's general focus on freedom of expression in Russia. The chapter illustrates how traditional media structures in modern Russia adapt historically sensitive narratives to the realities of social media. Both projects are variants of this adaptation process. Mikhail Zygar, the author of Project '1917 - Free History', has been a strong critic of the Kremlin. Before starting the project, he worked as the editor-in-chief for the oppositional TV channel Dozhd. In contrast, RT's \#1917Live originates from the opposite political camp as part of Russian state media.

Project '1917 - Free History' was launched in the fall of 2016. \#1917Live started in February 2017. Throughout 2017, the two projects experimented with archival documents and social media to recreate the events of the Russian Revolution. Commemorating the centenary in the form of historical reenactments, each project focused in its own way on historical characters, their experiences and records of their lives. Their shared philosophy was to replay the past as if social media had existed a hundred years ago. As this chapter aims to show, the projects differed in their background, technological approaches to social media and preferred target audiences. Towards the second half of the chapter, my analysis of these projects builds on the theoretical premises known in scholarship as the affective turn in social sciences and humanities (O’Sullivan 2001; Hemmings 2005; Clough 2008). When applied to history and historical reenactments, the emphasis then shifts to personal experiences and responses to the past rather than paying attention to conventional structural questions of history - major events, institutions, political leadership and social transformations (Agnew 2007; Landsberg 2015). 
This comparative study reflects on how current socio-political contexts and available social media tools may be linked to questions of authenticity and emotional response (affect) in historical reenactments. I pay attention to the language used in the projects. The language choice indicates whether the target audiences were primarily from Russia, Russian speakers or broader international audiences. Project '1917 - Free History' originally was in Russian, but a version was also developed in English. RT's \#1917Live was initially launched in three languages (Russian, English and Spanish), but the project soon abandoned Russian and reduced the scope of the Spanish versions, prioritizing the use of English.

I limit my analysis to Facebook and Twitter. While Project '1917 - Free History' used VK more actively (Wijermars 2018), only on Facebook did it maintain the versions in Russian and English, which justified their selection for this chapter. \#1917Live concentrated on Twitter. The projects opened accounts in other social media but did not develop them as much. To account for the participatory capacities of the projects, I consider social media likes and shares (or retweets) as indicators of their affectivity. The chapter, therefore, integrates readings of literature on the role of the media in historical reenactments and the hypothesized turn towards the primacy of affect.

\section{History in the Russian public sphere}

In modern Russia, history plays a distinct political role. In recent years, celebrations of the Victory Day marking the end of the Second World War in Europe, also known in Russia as the end of the Great Patriotic War (1941-1945), have inspired a multitude of historical projects in cinematography, art and mass media. As a rule, such projects depend on hefty government subsidies and the prominent role of state television (Hutchings and Rulyova 2009; Lassila 2013; Wijermars 2019). 
The projects discussed here, however, dealt with an earlier and less glorious past. The longlasting Russian Revolution had two major episodes. In February 1917, Emperor Nicholas II was forced to resign, transferring power to the Provisional Government. In October, the Bolsheviks seized power and set up a new Soviet government, triggering a civil war. At the same time, Russia was still involved in the First World War. The poor performance of the tsarist army was one of the harbingers of the Russian Revolution (Wildman 1980). In 1918, the First World War ended for Russia with territorial losses, the imperial family being secretly executed and the continuation of the civil war - none of which helped national pride.

This partly explains why the collapse of the Russian monarchy in 1917 has been a largely neglected topic in the Russian public sphere. The mainstream Russian news media - whether state-owned or otherwise controlled - reported on the centenary far less than they typically report on such key episodes of the Second World War as the Victory Day, the Battle of Stalingrad or the Siege of Leningrad. The very idea of the revolution, however, turned out to also be a sensitive topic for the Kremlin. Scholars Rendle and Retish (2017), in their introduction to the special issue of Revolutionary Russia, noted that people at the highest political levels of Russian government, including President Vladimir Putin, were unfairly passive and reluctant to talk about this historical period. Paying attention to revolutions contradicts the unifying dogmatic version of Russian history. It was also feared that such history could inspire political opposition. Accordingly, cultural memories about the Russian Revolution and the Second World War differ significantly. The Revolution raised controversial feelings that impede nation consolidation. Even more to the point, the very idea of revolution reminds the Russians of the possibility of changing the current political system. Therefore, the state has no interest in encouraging or 
sponsoring large-scale reenactments of the time of revolution, at least for domestic audiences (Rendle and Retish 2017).

Yet, it is impossible to escape discussions of the Russian Revolution that several generations of Soviet people annually celebrated, mythologized and documented during the Soviet era (see Kolonitskii 2009). For many Russians who grew up in the Soviet Union, this is still an intrinsic part of their cultural heritage and general knowledge. It would be wrong to say then that the centenary was entirely forgotten. It inspired a certain number of government officials, historians, public figures, journalists and other intellectuals to revisit the events of 1917 in different formats, including some notable examples of historical reenactments.

Historical reenactments, perhaps with the exception of some private reconstructions for the sake of a hobby, seek to make history public and create public engagement with history. They use archival and other historical materials in an attempt to describe the past through the eyes, experiences and behaviour of the people who lived through such events. Theatre is perhaps the most traditional form of reenactments. Other popular genres include living history museums, thematic festivals, battle reenactments and performances at historical tourist destinations (Gapps 2009; McCalman and Pickering 2010; Magelssen et al. 2011).

In 2017, several initiatives were developed to present the Russian Revolution to the public. History clubs, museums and theatres included the revolutionary theme in their events, exhibitions and performances, often highlighting a particular moment in history: strikes, the arrest of the emperor's family, their dramatic evacuation to Tobolsk or the decision by the Provisional Government to stay in the First World War in April 1917. History was addressed through old and new documentary films screened in small-scale museum settings. The Mariinsky Theatre experimented with a special event devoted to 1917 that included a role-playing 
performance by the popular punk and rock band Leningrad and its lead singer Sergei Shnurov. In another theatrical performance, the Moscow Gubernsky Theatre staged a reconstruction of the last days of the imperial family.

As for mass media attention given to the Russian Revolution, serious and accurate historical discussions appeared more regularly in smaller-scale independent media than in the central state media. The liberal radio station Ekho Moskvy and television channel Dozhd, for example, resisted the official low interest in the centenary by organizing numerous interviews and talk shows with historians, political scientists and oppositional politicians. The state-controlled TV channels Pervii Kanal and Rossiia 1 preferred fictional genres. In November 2017, they released two television series: Trotsky and Demon of the Revolution (Demon Revoliutsii) accordingly. Critics slammed them both for being inaccurate in the biographical details, demonizing the revolutionaries and drawing ominous parallels with modern political dissent in Russia (Carroll 2017; Kinopoisk 2017; Yaffa 2017). In a reverse logic, the anti-corruption protests that occurred in Russia in 2017 inspired some small-scale independent media to draw their own parallels with the events of 1917. They even influenced Project '1917 - Free History' to combine the past and the present agendas into one interactive landscape, albeit with limited audience participation (Wijermars 2018). In contrast, Widestedt's (2019) analysis demonstrates that RT's \#1917Live actively depoliticized the revolutionary protests by portraying them as random episodes disconnected from each other and from present politics.

Apart from the traditional aspects of mediated historical reenactments - collapsing the past into the present, the mixing of audio and visual elements, stylizations and archival aesthetics (Baron 2014; Koivunen 2016) - Project '1917 - Free History’ and \#1917Live represented a new type of 
historical reenactment. They added yet another dimension to the genre by inviting the audience to witness history through social media.

The two projects differed in how people could interact with them. Project '1917 - Free History' concentrated most of its efforts on its main website (www.project1917.ru) and only supplemented this core interface with accounts in social media (VK and Facebook). \#1917Live formally launched a website within RT's domain, but deployed the bulk of its content in Twitter feeds. The basic elements of such projects are the profile pages of historical characters and organizations, where moderators publish messages (posts or tweets) that can include textual information, attached images, links and hashtags. Moderators constructed the messages so that they interacted with other characters and narratives. External participants, the audience, could watch how the 'live' action unfolded simply by subscribing to selected profiles or receiving automatic updates on certain discussion feeds. But they could also interact with the content by commenting on and sharing it with their own social media contacts. In short, the projects not only generated their own internal reenactment space, but were also integrated with various social media in the same way as any other content producer on the internet.

Research shows that Twitter is more communication-oriented than Facebook (and arguably also VK, which functions in a similar way as Facebook). Twitter is suited to and is used more often for individual interaction with sources of information rather than for interpersonal communication and group dynamics, for which Facebook is more appropriate (Hughes et al. 2012; Halpern et al. 2017). For historians and history enthusiasts interested in the public dissemination of history, 'with the goal of enlightening both the public and participants as to conditions of life in the past' (Cook 2004, 487), reenactments are more authentic when they enhance social experience. For them, reenactment is a process of learning through other people 
and less through historical documents. In reenactments on social media, this becomes a question of choosing the right platform.

The interactive features of social media provide new ways to increase public participation. What if Vladimir Lenin could take a selfie, post it on social media and announce his plans for a strike? His ‘contemporaries' and modern-day followers, inside and outside Russia, would immediately know what he was up to and be able to react, send him a message and see how he answers. Lenin would not be real, of course, but played by someone living in the present, who studied his biography, accessed relevant documents and dared to improvise with respect to Lenin's social media activities and reactions. As with any historical reenactment, accuracy and authenticity are questions that can jeopardize a project's appeal and success.

\section{The authenticity of Project '1917 - Free History' and \#1917Live}

Project '1917 - Free History' aimed to connect publics and history not only to provide an entertaining version of it, but also to invite people to experience it through genuine historical sources. The main website for Project '1917 - Free History’ was designed with a functionality mimicking social networking sites. In addition, the project copied parts of its content to actual social media. Several hundred people who lived through 1917, some well-known and others rarely mentioned in traditional history, were recreated as individual profiles and narratives. Links with references to the full version of historical documents appeared in most storylines. One of the goals was to also counter the state-controlled narrative of Russian television. The dominant stereotype on television compared the Russian Revolution to the Arab Spring and the uprisings in the former Soviet states, especially in Georgia (2003) and Ukraine (2004). As the televised discourse implied, all of them received support from abroad and were not inspired by internal 
problems (Seddon 2017). The documented individual stories in Project '1917 - Free History' were meant to prove this allusion wrong.

The project was a combined effort, involving the work of journalists, historians, graphic designers and illustrators. A few dozen professionals volunteered to moderate and administer the work. The hidden part of that effort boiled down to archival work - finding and cataloguing original letters, memoirs, diaries and other documents from the revolutionary period. For its creators, the project was an attempt to understand the meaning of the year 1917 across different social classes and generations. The creators claimed that some unique documents they had discovered would be made public for the first time. The reenactment element resided in the fact that the project team collected archival documents, converted them into digital formats and published them in an imaginary online community on behalf of real historical characters that developed in real time. It meant that a document pertaining to a certain date in 1917 was released on the same date in 2017. A novel element, however, was in connecting those processed documents to form a coherent communication network, thus resembling modern social media practices.

Project '1917 - Free History' raised money from a variety of sponsors primarily to pay for its technical infrastructure. The project's website listed some 20 organizations that supported the work. Russia's state-owned bank Sberbank was the only financial institution on the list. Notably, the bank had its own publicity interest in helping the project, occasionally reminding participants that it was open and operating already at the time of the revolution. As an important financial instrument of those unstable times, Sberbank was proudly featured in several of the project's reenactment plots. For example, an interactive visualization showing the inside of one of the bank's central offices played scenes where famous historical characters came in, waited for an 
appointment and exchanged remarks. Another major contribution came from the Russian internet giant and popular search engine Yandex, which helped with technological solutions and hosting capacities. The rest of the list of partner organizations included museums, libraries, archives and publishers that helped with gaining access to and reproducing archive material.

Given RT's connections to the Russian state, it is reasonable to believe that \#1917Live must have been part of Russia's foreign media policy - namely, to legitimize Russian domestic and global politics (Simons 2014, 8; Yablokov 2015). The Russian Revolution was one of the most important events of the 20th century, one with global consequences. In a confrontation with Western interests, it was crucial that RT exploits this topic by setting the baseline agenda for international publics. Had RT ignored it, other foreign broadcasters could have taken over the discussion. In that respect, making \#1917Live part of RT's global media campaign did not contradict the low public profile of the Revolution inside official Russia. On the contrary, RT sought to tell foreign publics that the Revolution was 'one of the most uncertain periods of the Russian history of the 20th century, which saw an end to the rule of the Romanov dynasty' (RT 2016).

\#1917Live chose Twitter as its main communication platform, integrated into RT's website at www.1917.rt.com (moved to www.1917live.red in 2018). The interaction developed around the main account, @RT_1917, with about a hundred other accounts representing people, groups of people and organizations. Compared to Project '1917 - Free History', \#1917Live was less strict about historical authenticity, allowing fictional or not clearly attributable accounts, such as 'student Vladimir', 'Kronstadt sailors' and, of course, the network's central mouthpiece, @RT_1917, which served as a never-existing newspaper, the Russian Telegraph, and renamed by the Bolsheviks Revolutionary Times. 
Project ‘1917 - Free History’ and \#1917Live became two historical reenactments of a similarly large scale. Both shared some elements of social media use and digital communication, and yet they were essentially different in others. Comparing them, therefore, gives us a fuller picture of how traditional media actors - an independent group of volunteers headed by journalist Mikhail Zygar and the state-funded broadcaster RT - adapted their representations of history to the social media environment.

The two projects demonstrated different media approaches to retelling the history of the Revolution. Project ‘1917 - Free History’ positioned itself outside and even against the logic of traditional media organizations that decide what to tell us and how. It delegated communicative capacities to personified accounts. In contrast, RT's \#1917Live, while communicated through Twitter, pursued the explicitly centralized logic of mass media. The main information hub represented a fictional newspaper with an unambiguous account handle referring to RT. Dozens of other accounts were grouped around @RT_1917 in a tight network. While the project utilized hundreds of unique hashtags to help the viral spread of its messages, the ubiquitous use of the hashtag \#1917Live held the whole structure together.

Crucial for comparing the national and international scopes of such projects is the fact that Project '1917 - Free History' was originally in Russian and, with only a few months delay, a version was then launched in English. In fact, with this international advancement of its agenda, the project stepped into the primary domain of \#1917Live. The English version received support from the Pushkin House Foundation in London. Devoted to promoting Russian culture, the foundation formally is autonomous and financially independent of the Russian government. It receives donations from several British organizations that represent both the Russian diaspora and academic institutions, such as the London School of Economics. The foundation for the most 
part helped translate Project '1917 - Free History' into English and published a separate version of it for the English-speaking public.

Project '1917 - Free History' appeared more authentic than \#1917Live, for it operated with profiles representing only real historical characters and organizations. The relationship within the social networks and especially the 'friendship' ties were, of course, necessary improvizations by the moderators. For example, Project '1917 - Free History' told its audience that Aleksandr Kerensky, one of the central figures in the Provisional Government, had fifteen 'friends', while Vladimir Lenin established personal friendship ties with only eight other people. Although the moderators did not design any friendship ties between the two central characters and antagonists of the Russian Revolution, the reenactments of their personal correspondence and official documents were frequently cross-referenced as if they were part of a digitally cohesive group. Such contextual links thus appeared counter-intuitive, at least with respect to modern party politics, where ideological rivals rarely, if ever, promote the social media profiles of one another. The reenactments presented here also departed from authentic renderings of history by collapsing communication speed at different rates. Official documents and newspaper articles had a much slower production circle at the beginning of the 20th century than they do today; private letters were not exchanged as quickly as modern messaging, and they relied on postal delivery times that were subject to frequent delays; notes and diaries remained unknown for years. The social media imitations in these projects, however, followed a different logic of contemporary online publishing tools: the same production speed was applied to all types of messages, which appeared as updates in reverse chronology from the latest on top to the oldest further down the screen. 
Beyond these questions of authenticity, there was the more intriguing issue of what it felt like to be part of such reenactments. Project '1917 - Free History' and \#1917Live reconstructed social networks of the past (still more authentic in the former case and involving more fiction in the latter case). They built relational ties between historical characters and institutions, integrated them into modern social media, but only the participation of real people turned them into timetravel machines. Social networks of the past and present were conflated to trigger new experiences of both 1917 and 2017.

\section{The role of affect in historical reenactments}

Both projects aimed to reconstruct the past by paying attention to personalities and their social media profiles. They put the moderators and the audiences into a position where they could experience the past through immersion in the reality of those profiles. This emphasis on the private rather than on the public distinguishes what is called the affective turn in social theory. This section assesses the applicability of such a vision to Project '1917 - Free History' and \#1917Live.

In historiography, the affective turn means a shift in the way history appears in public (in schools, theatres and mass media), a departure from large-scale, events-based history and wellknown documents towards more trivial details seen from new angles or through personal experiences. The relatively new approach focusing on affects began to rapidly develop in the late 1990s. Scholars criticized previous approaches, claiming that post-structuralism, for example, was unable to grasp bodily the materialism of human subjects, the technological mediatization of senses and subjectivities (Clough 2008; Coole and Frost 2010). Studies of affect in historiography (see Reddy 2006; Mikula 2015) and media research (see Papacharissi and de Fatima Oliveira 2012; Papacharissi 2016), and their combinations (Agnew 2007; Landsberg 
2015; Koivunen 2016), followed the general developments in communication technologies. As Alison Landsberg argues, 'the main way in which contemporary, mass-mediated historical production differs from academic history is in its emphasis on the mobilization of affect' (2015, 178).

Therefore, media reinforce the affective turn. Affective thinking not only transforms the internal logic of historical reenactments, it also opens them to various interventions. Previously, historical reenactments for the most part attracted history enthusiasts and/or an elitist type of audience, and they rarely targeted wider audiences. Meanwhile, several studies have shown how reenactments organized with the help of mass media or presented through them allow for a more popular and mass experience of history (Cook 2004; Knutsen 2016; Rymsza-Pawlowska 2017). The use of the internet and social media for historical reenactments is still a novelty, especially beyond applications in small-scale, clearly defined publics, such as, for instance, history classes (McKenzie 2014). Therefore, larger projects, such as those discussed here, have drawn scholarly attention from a number of perspectives (Hutchings and Tolz 2017; Drezov 2018; Wijermars 2018; Widestedt 2019).

What remains unexplored is how reenactment projects adjust their historical knowledge to the socio-political intentions of the reenactors themselves and to the purpose of achieving wider publicity through social media. The reenactment projects discussed here used historical documents to transform their content into messages suitable for or similar to social media formats. This was the part where the projects initiated the reenactments but did not have full control over them. The materialization of the past entails a public response that can be conceptualized as affective. The reenactors and the audience are given tools to interact with historical characters, documents or episodes by emotionally responding to them. One concrete 
form of such a practice is the omnipresent 'like' button, which produces the so-called 'affective traffic' (van Dijck 2013, 162). Historical reenactments on Facebook and Twitter thus move beyond the academic accounts of the past that we find in history textbooks. Therefore, historical reenactments on social media not only involve the affective dimension on the part of the projects' authors and administrators, but also influence a generation of affective publics (Papacharissi 2016) whose feelings materialize in the forms of collaboration, co-authoring and sharing the experience of the revolution. The question is, to what extent were Project '1917 Free History' and \#1917Live indeed affective and what role did the audience play in that effort? According to the affective model, reenactments challenge traditional academic and educational approaches to studying and discussing history. They avoid definitive claims about past events, immersing participants in individual lives of the past and helping them experience and internalize that other reality and, as a result, provide a different way of learning. There are limits to those experiences, too. Reenactments cannot escape structural constraints. They demonstrate via the choice of historical characters a dependence on the structure of archival materials and presentation styles that was impossible in the past.

As Agnew $(2007,301)$ has noted in her study of a German historical TV series, the increased authenticity of affective reenactments collapses the time that spans the past and the present into a single epoch; it dissolves differences that are crucial to "further historical understanding and reconcile the past to the present'. Moreover, this collapse 'implies forms of historical continuity that are not only potentially inaccurate but also exploitable for ideological ends' (Agnew 2007, 309). Notable in that respect is the moment, mentioned earlier, when RT created a historical Twitter account for the UK Embassy. Its banning resonated with contemporary tensions and confrontations in the Russia-UK relation over, among other topics, the annexation of Crimea and 
the suspected Russian influence in Brexit. It becomes difficult to distinguish between ideological relationships of power, of who controls the discourse, as reenactments produce affects that are not individual, but rather, social and cultural forces linked to nation-building (see Koivunen 2016).

Alexander Cook $(2004,494)$, in his essay on 'The Use and Abuse of Historical Reenactment', proposed that the greatest benefit of reenactments does not come from their ability to retell the known facts of history, but from their ability to encourage the public to learn something new about their present with the help of history. This is precisely what social media's affective functionality enables - the co-production of reflexive moments about the meaning of revolutionary events for one's own national identity and imagination. Different media tools and content may have a profound effect on the outcome of such individual investigations spread across geographical locations.

\section{The affectivity of Project '1917 - Free History' and \#1917Live on social media}

The above-mentioned theoretical points informed my approach to this study of Project '1917 Free History' and \#1917Live. In this section, I focus on what the projects published in their social media reenactments and how the audiences reacted to those publications. I analysed how many posts were published, how many of them were original and how many were shared, and what were the metrics of user reactions (likes, shares and similar metrics). Thus, instead of conducting a conventional content analysis of social media posts, I employed a different approach to obtain a sense of how affectivity works. My main method of data collection consisted of monitoring the projects throughout the year 2017 and choosing a shorter moment in time to make a closer analysis of their activities with smaller samples. To secure the 
comparability of these subsamples (two retrieved from Facebook and one from Twitter, according to the projects), I focused on the first weeks of November, which also included the highest peak of activities on the day of the October Revolution (7 November in the modern calendar). In practical terms, I relied on the meta-data used by Facebook and Twitter to internally classify content. The data are available through application programming interfaces (APIs). For example, I distinguished between original and external content on social media. By original content, I mean those messages that can be attributed to the projects' own production teams, such as Facebook posts marked as 'added photo', 'added video', 'status update' or linked to the projects' websites. Similarly, original tweets were those posted by the project accounts or linked to them. External content, however, appeared as 'shared' on Facebook or as a 'retweet' on Twitter and led to external materials. I also compared messages that were textual only and those with added visual elements (pictures, maps, diagrams and videos). I compared the messages based on the numbers of shares, likes or favourites (for Twitter) they received as an indicator of affectivity. Previous studies of historical reenactments have advanced our understanding of affects in noninteractive forms of mass media, mainly television. The interactive nature of social media expands the earlier theoretical framework by adding a participatory dimension to the genre. The projects discussed here had clear strategies targeting either Russian speakers or international English-speaking audiences, or both. The advantage of open social media data is that we can estimate (through APIs) where those followers and participants came from. With due reservations about the reliability of geolocation based on IP addresses, we can map the projects geographically, and hence, reflect on the audience composition. 
In Project '1917 - Free History' on Facebook, the majority of the subscribers to the Russianlanguage version had IP addresses in Russia (75 per cent), followed by Ukraine (10 per cent), the USA (4.2 per cent), Germany (2.6 per cent) and the UK (2.2 per cent). The English-language version was the most popular in the USA ( 28 per cent) and the UK ( 22 per cent). Users from Russia were the third largest group of subscribers (16.5 per cent). These numbers indicate that Project '1917 - Free History' had no explicit geographically confined audience. Even its version in English attracted many users in Russia.

Nearly 6,000 unique users reacted to \#1917Live's content at @RT_1917 on 7 November. Of those users, almost 70 per cent had self-reported geotags on their locations, which roughly illustrates the geography of the project on that day. One-third of the users (33 per cent) who liked, commented on or retweeted @RT_1917's messages reported the USA or Canada as their location. The second largest group (10 per cent) were from the UK. Russian users were a minority group representing less than 3 per cent, which corresponds to RT's orientation towards international audiences. The use of English in both projects seemed to determine that at least half of the audience was North American or British.

The affective turn thesis suggests privileging details about people's private lives and experiences and paying less attention to specific dates and turning points. However, the projects' moderators, who were perhaps too entrenched in their rigid frameworks of conventional history education, made it clear that 7 November was a culmination of their reenactment efforts. Both projects were most active on that day, posting and sharing stories. I have monitored what the projects did on that day and summarized the data along with social media affective reactions (shares and likes) in Table 6.1. The Facebook-based projects published 26 (@ Project1917, in Russian) and 25 (@1917FreeHistory, in English) stories on that day. Compared to the overall outputs of 657 and 
707 posts throughout the year 2017 (3.7 posts a day), these numbers unequivocally demonstrate the date of 7 November as important. I found a similar trend at \#1917Live. The main account @RT_1917 tweeted 139 times, including 87 original tweets and 52 retweets. The total number of tweets and retweets on that day was more than ten times the average level from the week before and after.

The median levels of sharing (retweeting) and liking (favourites for Twitter) in Table 6.1 reveal the following tendencies. First, we can see that Project '1917 - Free History' on Facebook had a disproportionally higher range of differences between likes and shares, whereas for \#1917Live, those categories were closer to each other. People were less inclined to share content on Facebook, but were quite eager to express their feelings about it. Second, given the subscription differences between the two projects on Facebook, the active affective response (shares) to the Russian-language version was lower. Nonetheless, it displayed a passive response in terms of the numbers of likes per post, which was relatively similar to the English-language version.

Original content, which, by definition, constitutes the work of reenactors and should be related to higher degrees of authenticity, played a substantial role in how the projects developed. So, for example, the affectivity levels of the original tweets by @RT_1917 did not differ significantly from the retweets $(p=0.145)$. However, tweets with images were significantly more affective than tweets with text $(p<0.001)$. Facebook's internal algorithms are known to privilege original user posts and minimize the visibility of posts with links to external sources (DeVito 2017). Thus, subscribers to Project '1917 - Free History' had more chances to see the posts tailored for Facebook specifically rather than those linked to the project's website. Technically, the latter would be what the project actually did; hence, they would be more original. In that sense, originality played a more nuanced and intriguing role in reenactments copied to Facebook. What 
appeared on both Facebook projects as external content (50 per cent in Russian and 76 per cent in English) were, in fact, original reenactment stories from the projects' official websites, whereas Facebook-specific posts were merely additions or reworked stories. As a result, both language versions had significantly lower affectivity levels for external posts $(p=0.001$ in Russian and $p=0.22$ in English).

To assess the scope of this affectivity, we can compare the projects by the audience sizes they engaged. There are at least two ways to roughly estimate the audience size when analysing social media pages. First, the reported numbers of subscribers to the projects' accounts indicate their relative popularity and potential reach. These are the so-called followers, who at some point expressed their interest in the projects by clicking 'like' or 'follow' buttons - integral parts of social media functionality. Subscribers receive updates from the pages or accounts they choose to follow, but that does not mean they really continue paying attention to them or even see them in their news feeds, where notifications from friends and other liked content compete for the greater chance to appear on top.

<COMP: Place Table 6.1 Here>

Another way to measure the audience for the projects is to look at the numbers of users who not only subscribed to the content but also interacted with it: like, share or comment. To obtain a sense of that parameter, I used meta-data on user reactions to the posts published by the Facebook projects during the period of twelve months (January to December 2017) and RT's Twitter project for a period of two weeks (1-14 November 2017). Statistics on user reactions can also serve as an aggregated indicator of affectivity. The more reactions per user, the higher the average intensity of affect. Active users are, of course, always fewer than the number of followers who are only potential participants - not all subscribers decide to interact with the 
content they may have encountered. In this analysis, an active user differs from merely a subscriber by the fact of having liked, shared or commented on the projects' content at least once during the studied period.

As Table 6.1 shows, at the time of data collection (November 2017) Project ' 1917 - Free History' had approximately five times more Facebook subscribers to its version in Russian than to its English-language version and slightly fewer than the number of Twitter followers achieved by RT's central account @RT_1917. As for user activities, the Russian-language version of Project '1917 - Free History' had approximately 30,000 active Facebook users, or 75 per cent of the subscriber base. The most active ten per cent of these active users had ten or more interactions with the content. This means that the core group of users regularly involved in the project was quite small compared to the subscriber base, and most responses to the page were not systematic. Similar statistics for the English-language version of Project '1917 - Free History' revealed over 3,000 unique users who reacted to at least one of the published stories throughout the year (or 37 per cent of subscribers). The same criteria of taking the top ten per cent of those users revealed at least thirteen reactions per user, which is more than the core group for the Russian-language version.

RT's \#1917Live nominally had the largest Twitter subscription rate of the three projects. The level of engagement is difficult to compare with the level of engagement of Facebook users, though. The samples did not cover the same period (due to Twitter's restrictions on data retrieval). Twitter data only contained user ids for 'retweets' (analogous to sharing on Facebook) but not for 'favourites' (likes). The platforms are also different in their communicative dynamics. Nonetheless, the raw numbers on sharing and liking of the \#1917Live content correlated so strongly that we can assume the utility of using the former as an indicator of affectivity on 
Twitter. I found that during the two crucial weeks, approximately 1,300 unique users (2.2 per cent of subscribers) reacted to the posts on @ RT_1917, and the cut-off line for the most active ten per cent of these users was four retweets.

These results mean that the Russian-language version of Project '1917 - Free History' had a larger and more affective public; more of the subscribers actually participated, even though it could be just a one-time reaction. Fewer subscribers participated in the English-language version. They were less likely to demonstrate affective response (likes) and, instead, more eager to share what they saw. However, if we switch our attention to the active core group of English-language users, their affective engagement with the content was slightly higher, though this difference with the core group of Russian-language users was not statistically significant. Compared to both versions on Facebook, the affectivity of \#1917Live on Twitter looks much weaker.

What episodes of the historical reenactments were more affective, causing more people to like the content and possibly triggering more diverse emotions? Facebook allows users to distinguish between a simple 'like' and a number of other emotional responses, specifying whether they 'love', feel surprised ('wow'), 'sad', 'angry' or are amused by ('haha') the content. @Project1917 and @1917FreeHistory performed differently in this respect. The generic 'likes' were more common for Project '1917 - Free History' in English, while the Russian version generated a wider range of affects. The chances of a diversified emotional response were almost twice as high for the Russian-language page as for the English-language page $(p<0.001)$. This fact may be a result of the higher proportion of culturally grounded content that the project in Russian was able to mobilize and present in the form of pastiche and collage posts. The remixing of archival documents into demotivation posters, wordplays and historical parallels to modern Russian contexts is difficult, if not impossible, to repeat for an international audience. This 
difference, though, could also result from different traditions of digital content production and social media use.

\section{Discussion}

This chapter looked at three examples of social media use for historical reenactments of the Russian Revolution of 1917. The first two were the Russian-language and English-language versions of Project '1917 - Free History’ on Facebook. The third example, \#1917Live, used Twitter (@RT_1917) to target an international public in English. Project ‘1917 - Free History’ was the private initiative of a Russian journalist and it relied on volunteers and sponsorship. \#1917Live was a state-run project, part of the global media operations of the Russian foreign broadcaster RT. Therefore, these projects had partially overlapping target audiences, bridging as they did Russian domestic and global international domains. They also used two different communicative platforms as part of their reenactments, which complicates comparisons but broadens our understanding of their strategies. The projects displayed opposite approaches in terms of how historical reenactments could be adapted to social media - centred around one key communicator (The Russian Telegraph, or @ RT_1917 on Twitter) or more evenly distributed between multiple historical characters. The observed structural differences reflected the sociopolitical contexts of their production. Practices of the authoritative government offices can be seen in how RT's project favoured an institutional perspective over an individual one. In contrast, the civic format of Project '1917 - Free History' presupposed reliance on volunteers and sponsors.

Analysis of the projects' Facebook and Twitter practices (their content, user reactions and communicative patterns) provides mixed evidence in support of affective theory (a shift from structural and events-based history towards the primacy of affect and personal experience). The 
projects discussed here were driven by a conventional vision of the Russian Revolution. The natural increase in public interest of particular events and characters is a sign of a traditional knowledge of history. It seems the projects explicitly planned peak attention periods, with more posts and formats mobilized to reconstruct a few key dates. Only with such knowledge could the audience approach more personified narratives and trace individual stories. The state-run RT's project was slightly more conventional in its use of an institutional framework than was the independent Project '1917 - Free History’.

The results discussed in this chapter highlight the effect of blurring geographical and social boundaries, mixing national and international audiences, which may be associated with reduced affective capacities in some cases. The projects differed significantly in how they communicated history, what primary publics they were targeting and what affective reactions they sought to provoke. The choice of Russian did not mean that the audience was limited to people in the Russian Federation. Facebook, as the leading global social media platform, makes such projects attractive to other nations with large numbers of Russian speakers, Ukraine for instance, which might well have contributed to a different result than had VK, the Russian analogue of Facebook, been used instead, which Ukraine banned from use in its territory in May 2017. The choice by @RT_1917 to use English on Twitter and by @1917FreeHistory to use it on Facebook determined that nearly half their publics came from the USA, the UK and Canada, people whose experience with reenactments of the Russian Revolution differs significantly from that of the Russian speakers. Furthermore, the social media presence of the projects was only part of their overall publicity. That was the case especially for Project '1917 - Free History', which included much more content and more activities concentrated on the official website. As it turned out, my 
personal communication with project administrators (on Facebook on 18 September 2017) revealed that updating the Facebook pages was not so important for them.

While social media neglect national geographical and political boundaries, they at least partially retain linguistic barriers. The specificity of topics brought up by the projects discussed here seemingly transformed national publics into publics of different cultural and linguistic domains. It is, therefore, essential to take into account that historical knowledge reproduced via social media carries varying affective capacities inside and outside their contextual reference points, historical Russia in our case. At the beginning of 20th century, it was the revolutionary turmoil and the civil war that forced an initial wave of several million Russians to immigrate to other countries; those numbers have multiplied since then as a consequence of other dramatic developments. Descendants of those people may well constitute a substantial part of the international audience drawn to reenactments of the Russian Revolution.

To conclude, I would like to return to the example of Anna Pavlova and the question that served as the starting point for this chapter. Why was Anna Pavlova mentioned in one of the projects reenacting the Russian Revolution of 1917 ? Why was this episode so powerful and affective in terms of the public reactions it caused? The chapter hints at one plausible explanation. By the time of the revolution, Anna Pavlova was already a world-famous ballet dancer. A century ago, this fact did not automatically mean, as would be the case now, that there were numerous recordings and visual evidence of her career. In fact, there are surprisingly few archival documents about her. Watching her dancing in Havana, in a 14-second, black-and-white film of poor quality and with no audio, around the time of the February Revolution, became an event on its own, something that both the reenactors and their publics appreciated. Pavlova's reputation as a revolutionary in the ballet technique had nothing to do with the political revolution in Russia in 
1917. On a deeper cultural level, however, Pavlova became a symbol. She symbolizes those talented and successful young people who were welcomed abroad but who did not see as bright a future in their home country. In an affective historical perspective, it does not matter that she left Russia in 1912, before the so-called first wave of emigration when up to two million proponents of Imperial Russia fled the revolutionary and civil war turmoil. What matters is that modern publics extrapolate those historical details into their own experience of the present.

Table 6.1 Social media statistics for the three historical reenactment projects on 7 November 2017

\begin{tabular}{llll}
\hline & \multicolumn{2}{l}{ Project “1917 - Free History” } & \#1917Live \\
\hline Account name & @Project1917 & @1917FreeHistory & @RT_1917 \\
Language & Russian & English & English \\
Platform & Facebook & Facebook & Twitter \\
Subscribers & 40,000 & 8,000 & 58,000 \\
Posts & 26 & 25 & 139 \\
Shares* & 11 & 6 & 27 \\
Likes* & 94 & 20 & 37 \\
*median levels. & & &
\end{tabular}

\section{References}

Agnew, Vanessa 2007. "History's Affective Turn: Historical Reenactment and its Work in the Present." Rethinking History 11, no. 3: 299-312.

Baron, Jaimie. 2014. The Archive Effect: Found Footage and the Audiovisual Experience of History. New York: Routledge.

Carroll, Oliver. 2017. “Russian State-run TV Marks Revolution's Centenary with Surprise Series Recounting Rise and Fall of Leon Trotsky.” Independent, October 16. 
https://www.independent.co.uk/news/world/europe/russian-revolution-centenary-leon-trotskybiopic-channel-one-ussr-bolshevik-marxist-joseph-stalin-a8002636.html.

Clough, Patricia T. 2008. "The Affective Turn: Political Economy, Biomedia and Bodies."

Theory, Culture \& Society 25, no. 1: 1-22.

Cook, Alexander. 2004. "The Use and Abuse of Historical Reenactment: Thoughts on Recent Trends in Public History." Criticism 46, no. 3: 487-496.

Coole, Diana, and Samantha Frost. 2010. New Materialisms: Ontology. Agency, and Politics. Durham, NC and London: Duke University Press.

DeVito, Michael A. 2017. "From Editors to Algorithms: A Values-based Approach to Understanding Story Selection in the Facebook News Feed.” Digital Journalism 5, no. 6:753773.

Drezov, Kyril. 2018. "Project 1917 and RT: The Russian Revolution in the Age of Facebook and Twitter." Journal of Global Faultlines 4, no. 2: 163-166.

Gapps, Stephen. 2009. "Mobile Monuments: A View of Historical Reenactment and Authenticity from Inside the Costume Cupboard of History." Rethinking History 13, no. 3:395-409.

Halpern, Daniel, Sebastián Valenzuela, and James E. Katz. 2017. "We Face, I Tweet: How Different Social Media Influence Political Participation through Collective and Internal Efficacy.” Journal of Computer-Mediated Communication 22, no. 6: 320-336.

Hemmings, Clare. 2005. "Invoking Affect: Cultural Theory and the Ontological Turn." Cultural Studies 19 , no. 5: 548-567.

Hughes, David John, Moss Rowe, Mark Batey, and Andrew Lee. 2012. “A Tale of Two Sites: Twitter vs. Facebook and the Personality Predictors of Social Media Usage." Computers in Human Behavior 28, no. 2: 561-569.

Hutchings, Stephen, and Natalia Rulyova. 2009. "Commemorating the Past/Performing the Present: Television Coverage of the Second World War Victory Celebrations and the (de)Construction of Russian Nationhood." In The Post-Soviet Russian Media: Conflicting Signals, edited by Birgit Beumers, Stephen Hutchings and Natalia Rulyova, 137-155. London: Routledge.

Hutchings Stephen, and Vera Tolz, V. 2017. "Retweeting History: RT, the 1917 Revolution Anniversary and the Global Media Landscape." Paper presented at Transnational Russian Studies Symposium, Durham University 14-16 September 2017. 
Kinopoisk. 2017. “'Nenauchnaia fantastika': Istoriki o serialakh 'Demon revoliutsii’ i

‘Trotskii'.” Kinopoisk.ru, 10 November. https://www.kinopoisk.ru/article/3064991/

Knutsen, Ketil. 2016. “A History Didactic Experiment: The TV Series Anno in a Dramatist Perspective.” Rethinking History 20, no. 3:454-468.

Koivunen, Anu. 2016. "Affective Historiography: Archival Aesthetics and the Temporalities of Televisual Nation-Building.” International Journal of Communication 10: 5270-5283.

Kolonitskii, Boris. 2009. "Russian Historiography of the 1917 Revolution: New Challenges to Old Paradigms?." History \& Memory 21, no. 2: 34-59.

Landsberg, Alison. 2015. Engaging the Past: Mass Culture and the Production of Historical Knowledge. New York: Columbia University.

Lassila, Jussi. 2013. "Witnessing War, Globalizing Victory.” In Memory, Conflict and Social Media: Web Wars in Post-Soviet States, edited by Ellen Rutten, Julie Fedor and Vera Zvereva, 215-227. New York: Routledge.

Magelssen, Scott, Rhona Justice-Malloy, Leigh Clemons, Catherine H. Hughes, Kimberly Tony Korol-Evans, and Lindsay Adamson Livingston. 2011. Enacting History. Tuscaloosa: The University of Alabama Press.

McCalman, Iain, and Paul A. Pickering. 2010. Historical Reenactment: From Realism to the Affective Turn. New York: Palgrave Macmillan.

McKenzie, Brian A. 2014. "Teaching Twitter: Re-enacting the Paris Commune and the Battle of Stalingrad." The History Teacher 47, no. 3: 355-372.

Mikula, Maja. 2015. "Historical Re-enactment: Narrativity, Affect and the Sublime." Rethinking History 19, no. 4: 583-601.

O’Sullivan, Simon. 2001. "The Aesthetics of Affect: Thinking art beyond Representation." Angelaki: Journal of Theoretical Humanities 6, no. 3: 125-135.

Papacharissi, Zizi. 2016. "Affective Publics and Structures of Storytelling: Sentiment, Events and Mediality." Information, Communication \& Society 19, no. 3: 307-324.

Papacharissi, Zizi, and Maria de Fatima Oliveira. 2012. "Affective News and Networked Publics: The Rhythms of News Storytelling on\# Egypt." Journal of Communication 62, no. 2: $266-282$.

Project 1917. 2017. “Anna Pavlova in Havana.” Project '1917 - Free History' on Facebook, 13 February. https://www.facebook.com/1790312207886282_1822130441371125. 
Reddy, William M. 2006. The Navigation of Feeling: A Framework for the History of Emotions, Cambridge: Cambridge University Press.

Rendle, Matthew, and Aaron Benyamin Retish. 2017. "The 'Lessons' of 1917." Revolutionary Russia 30, no. 1: 1-5.

RT. 2016. “\#1917LIVE: Relive the Russian Revolution as it Happened with RT's unique Twitter Project,” 31 December. https://www.rt.com/news/372353-russia-1917-revolution-news/.

Rymsza-Pawlowska, Malgorzata J. 2017. History Comes Alive: Public History and Popular Culture in the 1970s. Chapel Hill: The University of North Carolina Press.

Seddon, Max. 2017. "Like, Share, Tweet: Social Media Meets the Russian Revolution." Financial Times, 10 March. https://www.ft.com/content/c270e004-04b4-11e7-ace01 ce02ef0def9.

Simons, Greg. 2014. "Russian Public Diplomacy in the 21st Century: Structure, Means and Message." Public Relations Review 40, no. 3: 440-449.

Van Dijck, José. 2013. The Culture of Connectivity: A Critical History of Social Media. Oxford: Oxford University Press.

Widestedt, Kristina. 2019. "Breaking News from Petrograd, 1917: Remediated Revolution as Popular History." In Screening Protest: Visual Narratives of Dissent across Time, Space and Genre, edited by Alexa Robertson, 230-247. London: Routledge.

Wijermars, Mariëlle. 2018. "Project '1917 - Free History': Reliving the Russian Revolution in the Digital Age." Studies in Russian, Eurasian and Central European New Media (digitalicons.org), no. 18: 45-65.

Wijermars, Mariëlle. 2019. Memory Politics in Contemporary Russia: Television, Cinema and the State. London: Routledge.

Wildman, Allan K. 1980. The End of the Russian Imperial Army: The Old Army and the Soldiers' Revolt (March-April 1917). Princeton, NJ: Princeton University Press.

Yablokov, Ilya. 2015. "Conspiracy Theories as a Russian Public Diplomacy Tool: The Case of Russia Today (RT).” Politics 35, no. 3-4:301-315.

Yaffa, Joshua. 2017. "Putin's Russia Wrestles with the Meaning of Trotsky and Revolution." The New Yorker, 7 November. https://www.newyorker.com/sections/news/putins-russiawrestles-with-the-meaning-of-trotsky-and-revolution. 